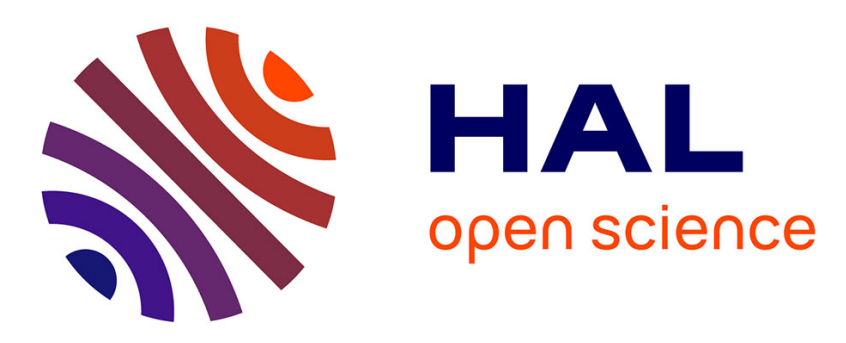

\title{
Subcellular Distribution of Dietary Methyl-Mercury in Gammarus fossarum and Its Impact on the Amphipod Proteome
}

Claudia Cosio, Davide Degli-Esposti, Christine Almunia, Véronique Gaillet, Hervé Sartelet, Jean Armengaud, Arnaud Chaumot, Olivier Geffard, Alain Geffard

\section{To cite this version:}

Claudia Cosio, Davide Degli-Esposti, Christine Almunia, Véronique Gaillet, Hervé Sartelet, et al.. Subcellular Distribution of Dietary Methyl-Mercury in Gammarus fossarum and Its Impact on the Amphipod Proteome. Environmental Science and Technology, 2021, 55 (15), pp.10514 - 10523. 10.1021/acs.est.1c02385 . hal-03376460

\section{HAL Id: hal-03376460 https://hal.science/hal-03376460}

Submitted on 18 Oct 2021

HAL is a multi-disciplinary open access archive for the deposit and dissemination of scientific research documents, whether they are published or not. The documents may come from teaching and research institutions in France or abroad, or from public or private research centers.
L'archive ouverte pluridisciplinaire HAL, est destinée au dépôt et à la diffusion de documents scientifiques de niveau recherche, publiés ou non, émanant des établissements d'enseignement et de recherche français ou étrangers, des laboratoires publics ou privés. 


\section{Subcellular distribution of dietary methyl-mercury in Gammarus}

\section{2 fossarum and its impact on the amphipod proteome}

3

$4{\text { Claudia } \operatorname{Cosio}^{\mathrm{a} *} \text {, Davide Degli-Esposti }}^{\mathrm{b}}$, Christine Almunia ${ }^{\mathrm{c}}$, Véronique Gaillet ${ }^{\mathrm{a}}$, Hervé

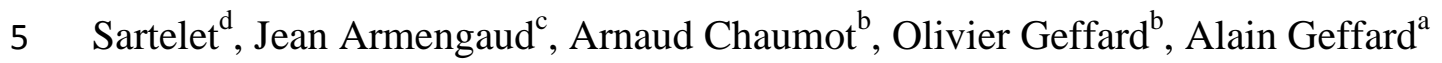

6

7

8

9

10

11

${ }^{a}$ Université de Reims Champagne-Ardenne, UMR-I 02 INERIS-URCA-ULH SEBIO,

Campus du Moulin de la Housse, CEDEX, Reims, BP 1039 51687, France

b INRAE,UR RiverLy, Laboratoire d'écotoxicologie, F-69625 Villeurbanne, France.

${ }^{\mathrm{c}}$ Université Paris-Saclay, CEA, INRAE, Département Médicaments et Technologies pour la Santé (DMTS), SPI, 30200 Bagnols-sur-Cèze, France

${ }^{\mathrm{d}}$ Université de Reims Champagne-Ardenne, UMR CNRS/URCA 7369, Matrice

Extracellulaire et Dynamique Cellulaire (MEDyC), Campus du Moulin de la Housse,

CEDEX, Reims, BP 1039 51687, France

*Corresponding author: Claudia.Cosio@ univ-reims.fr, 


\section{Abstract}

The transfer of methyl- $\mathrm{Hg}(\mathrm{MeHg})$ from food is central for its effects in aquatic animals, but we still lack knowledge concerning its impact in invertebrate primary consumers. In aquatic environments, cell walls of plants are particularly recalcitrant to degradation and as such remain available as food source for long periods. Here, the impact at the proteomic level of dietary MeHg in Gammarus fossarum was established and linked to subcellular distribution of $\mathrm{Hg}$.

Individuals of G. fossarum were fed with $\mathrm{MeHg}$ in cell wall or intracellular compartments of Elodea nuttallii. $\mathrm{Hg}$ concentrations in subcellular fractions were 2 to $6 \mathrm{x}$ higher in animals fed with cell wall than intracellular compartments. At the higher concentrations tested, the proportion of $\mathrm{Hg}$ in metal sensitive fraction increased from $30.0 \pm 6.1 \%$ to $41.0 \pm 5.7 \%$ for individuals fed with intracellular compartment, while biologically detoxified metals fraction increased from $30.0 \pm 6.1 \%$ to $50.0 \pm 2.8 \%$ when fed with cell wall compartment. Data suggested that several thresholds of proteomic response are triggered by increased bioaccumulation in each subcellular fraction in correlation with $\mathrm{Hg}$ exclusively bound to the metal sensitive fraction, while the increase of biologically detoxified metal likely had a cost for fitness. Proteomics analysis supported that the different binding sites and speciation in shoots subsequently resulted in different fate and cellular toxicity pathways to consumers.

Our data confirmed that $\mathrm{Hg}$ bound in cell walls of plants can be assimilated by G. fossarum, which is consistent with its feeding strategy, hence pointing cell walls as a significant source for $\mathrm{Hg}$ transfers and toxicity in primary consumers. The high accumulation of $\mathrm{Hg}$ in macrophytes make them a risk for food web transfer in shallow ecosystems. The present results allowed gaining new insights on the effects and uptake mechanisms of $\mathrm{MeHg}$ in aquatic primary consumers.

Keywords: bioaccumulation; cell walls; cytosol; proteogenomics; subcellular distribution.

Synopsis: subcellular compartmentalization of $\mathrm{MeHg}$ in shoots determines its fate and toxicity in primary consumers 
53

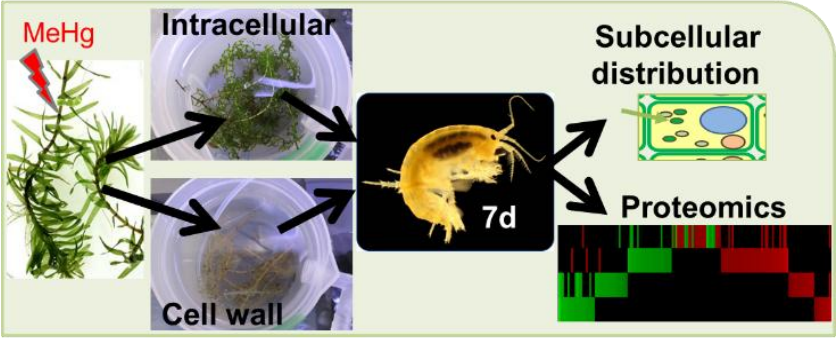

54 


\section{Introduction}

Mercury $(\mathrm{Hg})$ is a global pollutant seriously threatening ecosystems and eventually health, due to the biomagnification of methyl- $\mathrm{Hg}(\mathrm{MeHg})$ through the food chain ${ }^{1,2,3}$. Past $\mathrm{Hg}$ deposits of anthropogenic sources continue to cycle through compartments, forming up to $60 \%$ of current $\mathrm{Hg}$ emissions ${ }^{4}$. Consequently, even if new emissions of $\mathrm{Hg}$ are kept constant, $\mathrm{Hg}$ deposition will increase in the future ${ }^{5,6,7}$. In this context, understanding how $\mathrm{Hg}$ is bioaccumulated and biomagnified in food webs is central to increase the effectiveness of environmental management programs for biota and human health. For example, aquatic plants are key species in shallow aquatic environment in which $\mathrm{MeHg}$ is formed ${ }^{8}$. The high accumulation of $\mathrm{Hg}$ in aquatic plants make them considered a model species for phytoremediation programs, biomonitoring or to perform ecotoxicological tests ${ }^{9}$, but also at risk for food web transfer ${ }^{10,11}$. A current research priority is to establish the sources of dietary $\mathrm{Hg}$ having a detrimental impact in aquatic plant-based food webs for mitigation programs.

Both inorganic $\mathrm{Hg}(\mathrm{IHg})$ and $\mathrm{MeHg}$ are bioaccumulated in biota. While $\mathrm{MeHg}$ generally represents 0.05 to $1 \%$ and up to $30 \%$ of total $\mathrm{Hg}(\mathrm{THg}=\mathrm{IHg}+\mathrm{MeHg})$ in water, $\mathrm{MeHg}$ forms up to $80-100 \%$ of the $\mathrm{THg}$ in fish muscles, resulting in very high toxic body burdens in fish, therefore threatening humans' health through fish consumption 2, 12, 13. Consequently, although both $\mathrm{IHg}$ and $\mathrm{MeHg}$ trigger toxicity in biota, in animals dietary $\mathrm{MeHg}$ is the main risk of $\mathrm{Hg}^{2,12}$. Nonetheless, a major gap in knowledge concerns the impact of dietary $\mathrm{Hg}$ uptake in invertebrate primary consumers. Data supported the oxidative stress to be central for $\mathrm{MeHg}$ toxicity in aquatic animals ${ }^{14,15}$, but few studies concern effects through diet at environmental concentrations and none concern invertebrates ${ }^{16}$. In this context, the impact of $\mathrm{MeHg}$ in realistic environmental exposure scenarios and representative biota need to be studied to better anticipate its potential environmental impact. In aquatic invertebrates, toxicity and tolerance of metal accumulation can be explained by its subcellular partitioning ${ }^{17}$. For example, in biota the sequestration of toxic metal by metallothioneins and granules is known as biologically detoxified metals (BDM), while the partition in the metal sensitive fraction (MSF) is expected to cause the toxicity ${ }^{17,18}$. Moreover, linking intracellular concentration and distribution to molecular and cellular responses is a current research priority in biomonitoring, as it could participate in revealing innovative biomarkers for environmental risk assessment ${ }^{9,19}$.

Pioneer studies on diatoms suggested that intracellular $\mathrm{MeHg}$ was primarily transferred to copepods, while $\mathrm{Hg}$ from cell walls, consisting in silicate frustules, was not assimilated ${ }^{20}$. By contrast, we recently demonstrated that $\mathrm{IHg}$ and $\mathrm{MeHg}$ from cell walls -formed primarily of 
cellulose, hemicellulose and pectin- in shoots of the macrophyte Elodea nuttallii resulted in a higher transfer to gammarids than intracellular $\mathrm{Hg}{ }^{10}$. Similarly, chironomids fed with shopped macrophytes, to mimic incorporation in sediments of decaying tissues, revealed that $\mathrm{MeHg}$ was more transferable to sensitive subcellular targets and bioavailable fraction in primary consumers than IHg found in intracellular or cell wall compartments ${ }^{11}$. Data point that the composition of cell walls could affect the transfer rate of $\mathrm{Hg}$ to consumers ${ }^{10,11,21}$. The proportion of diatoms in phytoplankton is particularly high in nutrient-rich marine coastal and high latitudes ecosystems, but significantly less in freshwater rivers, lakes and other environments ${ }^{22,23,24}$. In this context, data concerning $\mathrm{Hg}$ food transfer in marine plankton might not be generalized to other animals with distinct feeding strategies or other ecosystems, including freshwater, brackish water or contaminated sites. Moreover, studies on effect of trophic $\mathrm{Hg}$ exposure in primary consumers, i.e. invertebrates are rare $10,11,21$. At environmental concentrations, cell walls appeared as the main bioaccumulation compartment of $\mathrm{Hg}$ in macrophytes and because of their low degradability are expected to remain for long periods in the aquatic systems, likely serving as food source ${ }^{25,26,27}$. Here, we hypothesized that the biding of Hg to plant's cell walls results in a higher dietary transfer and subsequently in a higher toxicity in primary consumers than $\mathrm{Hg}$ bound in plant's intracellular compartment. Gammarids as generalist herbivores are instrumental in European lotic ecosystems food webs because of their role in the breakdown of the leaf litter. They are also good bioaccumulators of metals and good candidates for ecotoxicological testing of freshwater ecosystems 19,28 . Gammarus spp are found in E. nuttallii beds and were previously reported to feed on the latter 29, 30 . Here we aimed to address how the MeHg localization in E. nuttallii shoots (cell wall vs intracellular) defines its subcellular distribution in G. fossarum; and how dietary $\mathrm{MeHg}$ impacts the proteome of G. fossarum. Gammarids were fed for 7 days with either cell wall or intracellular compartment of the plant E. nuttallii previously exposed to $\mathrm{MeHg}$ and we analyzed the fate and effects of $\mathrm{MeHg}$ in animals through subcellular distribution and shotgun proteomics. Extensive proteome profiles further revealed the molecular toxicity pathway of dietary MeHg. This fundamental knowledge contributes to a better knowledge of the fate and impact of dietary $\mathrm{MeHg}$ in food webs.

\section{Material and Methods}

\section{Labware cleaning}

Glasswares and plastic consumables for exposures and sampling were washed for once in detergent, twice in $10 \% \mathrm{HNO}_{3}$, once in $10 \% \mathrm{HCl}$, rinsed after each washing step with MilliQ 
water (Merck Millipore) and kept in a laminar flow hood until dry. Glass material was in addition heated overnight at $200^{\circ} \mathrm{C}$.

\section{Elodea nuttallii and Gammarus fossarum exposure}

Exposure protocols of E. nuttallii and G. fossarum were described in ${ }^{10}$. Briefly, shoots were collected in Etournels pounds and acclimated $48 \mathrm{~h}$ in laboratory conditions. Shoots $(10 \mathrm{~cm})$ without roots were exposed to $\mathrm{MeHg}\left(\mathrm{CH}_{3} \mathrm{HgCl}\right.$; Alfa Aesar) or not exposed (control). The exposure concentrations in water were chosen based on previous studies to result in concentrations in shoots after $2 \mathrm{~h}$-long exposure spanning lowly to highly contaminated environments (Table S1) ${ }^{2,31}$, After the exposure, shoots were washed to conserve the shoot morphology and retain $\mathrm{Hg}$ either from intracellular or cell wall compartment. Briefly, intracellular $\mathrm{Hg}$ was conserved in shoots by rinsing with $10^{-3} \mathrm{M}$ EDTA (AppliChem) and $10^{-3}$ $\mathrm{M}$ cysteine (Sigma-Aldrich) to remove the extracellular loosely bound $\mathrm{Hg}^{8} . \mathrm{Hg}$ bound in the cell wall were obtained by soaking shoots in methanol-chloroform 3d (Sigma), resulting in lipids solubilization and consequently allowing to recover an intact insoluble cell wall matrix with a conserved structure ${ }^{32}$. This latter method affects cell integrity and organic solvents could cause $\mathrm{IHg}$ and $\mathrm{MeHg}$ redistribution. As such, concentrations might not be strictly representative of initial concentrations in shoots but was performed to allow feeding animals with purified cell walls.

Gammarus fossarum were sampled in the Bourbre River (France) ${ }^{33,34}$, and acclimatized three weeks to laboratory conditions. Nine $1 \mathrm{~cm}$-long males were fed during 7 days with E. nuttallii intracellular (I) or the cell wall (CW) compartments pre-exposed to 4 and $20 \mu \mathrm{g} \mathrm{L}^{-1} \mathrm{MeHg}$ concentrations, thereafter referred as 'low' and 'high' $\mathrm{MeHg}$ treatments in line with their concentrations corresponding to lowly and highly contaminated environments, respectively ${ }^{2}$, 10, 11, 31 . To ensure exclusive exposure of gammarids through plant consumption, water renewal and daily removal of dead individuals was done to avoid exposure to $\mathrm{Hg}$ through water or cannibalism, respectively. We observed a weak (15\%) mortality of gammarids during exposure in all conditions ${ }^{10}$. This rate agrees with the criteria from the Afnor standard (XP T 90-722-3) for feeding rate measurement in the sentinel species . $_{\text {. fossarum }}{ }^{35}$. It was not correlated with $\mathrm{MeHg}$ concentration, or with the plant compartment (intracellular/cell wall) and supported an absence or a sublethal toxicity in these experimental conditions ${ }^{10}$. No depuration was applied here, based on a former study, using the same experimental exposure conditions showed that a 7 day-long depuration didn't varied $\mathrm{Hg}$ concentrations ${ }^{10}$. 
Subcellular fractionation of $\mathrm{Hg}$ in Gammarus fossarum

158 The fractionation procedure of the whole body (Figure 1) adapted from ${ }^{17,36}$ was described elsewhere ${ }^{37}$. Analyses were done in triplicates. Two frozen gammarids per conditions were homogenized in $1 \mathrm{~mL}$ of ice-cold buffer (0.02M Tris-HCl pH 7.5; Sigma-Aldrich, purity $99 \%$ ). The homogenate $(\mathrm{H})$ was centrifuged $30 \mathrm{~min}$ at $4^{\circ} \mathrm{C}$ at $10,000 \mathrm{~g}$. The pellet $(\mathrm{P} 1)$ was hydrolyzed at $100^{\circ} \mathrm{C} 2 \mathrm{~min}$ and $1 \mathrm{~h}$ with $1 \mathrm{M} \mathrm{NaOH} 65^{\circ} \mathrm{C}$ and centrifuged $10 \mathrm{~min}$ at $10^{\circ} \mathrm{C}$ at $10,000 \mathrm{~g}$, resulting in a supernatant including gut content, cellular debris and likely part of mitochondria (S2), while the pellet contained metal-rich granules and exoskeleton (P2). The supernatant (S1) was ultracentrifuged $30 \mathrm{~min}$ at $4^{\circ} \mathrm{C}$ at $100,000 \mathrm{~g}$ forming a pellet (P3) including lysosomes and microsomes and a supernatant (S3) with the cytosol. However, no marker enzymes (i.e. ${ }^{38,39}$ ) was used to confirm further the nature of each subcellular fraction besides operational fractions according to ${ }^{17}$. All S3 was further filtered with a sterivex filter (millipore) at $0.45 \mu \mathrm{m}$, and thereafter named S4.

170

171

172

High-performance liquid chromatography (HPLC) was performed to fractionate S4 with a column using steric exclusion allowing (BIOSEP-SEC-S 2000; 1 - 300 kDa; Figure S1). Eluting fractions of $0.5 \mathrm{~mL}$ were collected up $18 \mathrm{~mL}$, acidified at $0.5 \%$ with suprapur $\mathrm{HCl}$ (Merx) and kept at $4^{\circ} \mathrm{C}$ until analyzed. Three pools of metal-ligand were separated: (i) highmolecular weight (HMW; 20-255 $\mathrm{kDa}$ ) eluting 9 to $15 \mathrm{~min}$ after injection, (ii) metallothionein-like protein eluting 16 to 24 min after injection (MTLPs-MW; 1.8-20-kDa) and (iii) low-molecular weight (LMW; <1.8 kDa) eluting 25 to 35 min after injection. Using this protocol, MTLPs-MW are biologically detoxified metal in cytosol, while the heat sensitive protein (HSeP) or proteins in cytosol is the sum of HMW and LMW ${ }^{36}$. We also summed the area of peaks at $280 \mathrm{~nm}$ in these three fractions and normalized them by the biomass used in $\mathrm{H}$. We eventually compared the sum of $\mathrm{Hg}$ amounts found in the different subcellular fractions with the fraction $\mathrm{H}$, using $\mathrm{H}=\mathrm{P} 2+\mathrm{S} 2+\mathrm{P} 3+\mathrm{HMW}+\mathrm{MMW}+\mathrm{LMW}$ as a quality control, and observed a good agreement $(n=18: 93.4 \pm 4.9 \%)$. We also injected periodically $1 \mathrm{mM}$ EDTA using the same mobile phase to wash the HPLC column and to verify that $\mathrm{Hg}$ concentrations in eluting fractions remained at background level. For the biological interpretation, metal sensitive fraction (MSF) was calculated as $\mathrm{P} 3+\mathrm{HSeP}$ and biologically detoxified metals (BDM) as P2 + MTLPs-MW. As such, MSF + BDM + S2 = H. 
Determination of $\mathrm{Hg}$ in gammarids

189

190

191

192

193

194

195

196

197

198

199

200

201

202

203

204

205

206

207

208

209

210

211

212

213

214

215

216

217

218

219

220

Pellets, i.e. P2 and P3 fractions, were resuspended in $1 \mathrm{~mL}$ water and mineralized $12 \mathrm{~h}$ at $60^{\circ} \mathrm{C}$ $30 \% \mathrm{HNO}_{3}$ (suprapur, Merck). THg concentration in P2, S2, P3, S4, MTPLs and HSeP were measured with a MERX-T analytical system (Brooks Rand instrumentsA) using THg method 40 showing a limit of detection (DL) of $0.03 \mathrm{ng} \cdot \mathrm{THg} \cdot \mathrm{L}^{-1}$, an error of $2 \%$ using certified reference materials (CRMs) ORMS-5 (95.0 $\pm 1.7 \%$ recovery) and TORT-2 (100 $\pm 0.1 \%$ recovery). MeHg was analyzed in P2, S2, P3, S4, MTPLs and HSeP samples with a MERXM (Brooks Rand instruments) using MeHg method ${ }^{41,42}$ showing a DL of $0.002 \mathrm{ng} \cdot \mathrm{MeHg} \cdot \mathrm{L}^{-1}$, an error of $15 \%$ using the CRM TORT-2 (102.5 $\pm 2.4 \%$ recovery).

Data are presented as arithmetic means \pm standard deviations (SD). Normality and homoscedasticity were tested. An analysis of variance (ANOVA, $p<0.05$ ) with a post-hoc Tukey's HSD test $(p<0.05)$ was used to perform pairwise comparisons of bioaccumulation in the software $\mathrm{R}$ version $3.1 .3^{43}$.

\section{Protein extraction and Tandem mass spectrometry}

Proteins were extracted $(n=6)$ from individuals of $G$. fossarum and identified following the same protocol as formerly described ${ }^{44}$. Briefly, each animal was subjected to a bead beating homogenization using a single $3.2 \mathrm{~mm}$ steel bead per tube in LDS buffer $\left(20 \mu \mathrm{l} \cdot \mathrm{mg}^{-1}\right.$; Invitrogen). Cellular debris were eliminated after centrifugation for $3 \mathrm{~min}$ at $10,000 \mathrm{~g}$. Proteins from the supernatant were denatured for $5 \mathrm{~min}$ at $99{ }^{\circ} \mathrm{C}$. An aliquot of $20 \mu \mathrm{L}$ was then loaded onto a SDS-PAGE gel for a brief $(5 \mathrm{~min})$ electrophoresis as recommended ${ }^{45}$. Each proteome sample was processed and proteolyzed with trypsin (Roche) in ProteaseMAX surfactant $\left(0.01 \%\right.$, Promega) as recommended ${ }^{46}$. Peptides were analyzed with a Q-Exactive HF mass spectrometer (Thermo) operated in data-dependent mode with the same parameters as previously described ${ }^{47}$. Peptides were resolved at a flow rate of $0.2 \mu \mathrm{L} \cdot \mathrm{min}^{-1}$ along a 90 min gradient of $\mathrm{CH}_{3} \mathrm{CN}$ in presence of $0.1 \%$ formic acid.

\section{Peptide identification and proteomic data analysis}

MS/MS spectra were interpreted against the GFOSS database, that is available through PRIDE (accession PXD024583 as GFOSS_db01.fasta) with the MASCOT software (Matrix Science) and the same parameters as those previously described ${ }^{48}$. Proteins were validated on the basis of at least two identified peptides, resulting in a false discovery rate (FDR) lower than $1 \%$ as estimated with the decoy database search option. Abundance of each peptide was 
measured by their Spectral Count (SC), which corresponds to the count of MS/MS spectra attributed to the same peptide. The protein abundance is the sum of the SC of all the peptides assigned to the protein. Protein abundances were compared between organisms fed with control plants or plants pre-exposed to MeHg. Abundance of Methionine and Cysteine residue content in proteins from each sample was calculated by extracting spectral counts of these residues as previously proposed ${ }^{49}$, i.e. multiplying the spectral counts of each protein by its number of S-containing residues. The weighted relative abundance in S-containing residues was then obtained by dividing the sum of S-spectral counts by the sum of spectral counts of all residues.

Proteomics data have been deposited to the ProteomeXchange Consortium via PRIDE ${ }^{50}$ with the dataset identifier PXD024583 and project DOI 10.6019/ PXD024583

\section{Gene Ontology (GO term) functional annotation, classification and analysis}

Identified proteins were annotated in April 2018 using Swissprot (https://www.uniprot.org/) and NCBInr (https://www.ncbi.nlm.nih.gov/protein/) as databases explored with Diamond, a free high-throughput sequence aligner ${ }^{51}$. The NCBInr database was used to find the most probable protein homolog of the closest species to Gammarus fossarum for each protein with an e-value below $10^{-10}$. The Swissprot database was used to find the top 5 closest proteins in terms of sequence identity to define for each identified protein their biological processes and molecular functions as previously described ${ }^{52}$, selecting a bit score alignment above 20 and an e-value below $10^{-4}$.

\section{Differential proteomics}

The quantities of each protein in animals exposed to treated intracellular or cell wall compartments vs non-treated intracellular or cell wall compartments respectively were compared using Patternlab version $4.0{ }^{53}$. The L-stringency was set at 0.6. At least four measurements out of the five replicates per condition were taken into account. The selected data were normalized with the total signal. Proteins were distinguished into 4 groups: the first one corresponds to proteins that satisfied both the F-stringency $(<0.30)$ and statistical criterion (FDR < 0.05); the second one was filtered out by their L-stringency because of the low protein abundance; the third one groups proteins that meet only the fold criterion, and the fourth one comprises proteins that did not satisfy both criteria. Proteins from the first group were selected for the Gene Ontology (GO) slim differential analysis. The average percentage 
of S-containing residues in proteins significantly modulated, either over-detected or lessdetected, for each comparative test was calculated without specific weight.

\section{GO slim differential analysis}

GO slim analysis was performed taking the sum of SC of each GO slim related proteins for each sample. Univariate statistical analysis was performed to define, with the Ttest pValue, the reliability between conditions taking into account the six replicates. The ratio $\mathrm{R}$ for each GO slim was calculated for comparing treated conditions and non-treated conditions, either for the intracellular or the cell wall compartment, as the sum of SC of all replicates in the treated samples divided by the sum of SC of all replicates in the control samples. The ratio was compared using "prcomp" from the basic stats package of $\mathrm{R}$ to perform a Principal Component Analysis (PCA). From the PCA, significant GOSlim contributing for more than $50 \%$ to distinguish each condition (contrib $>0.5$ ) were extracted.

\section{Results and discussion}

\section{Accumulation and subcellular distribution of $\mathrm{Hg}$ in $\mathrm{G}$. fossarum}

$\mathrm{THg}$ concentrations in subcellular fractions were 2 to $6 \mathrm{x}$ higher in animals fed with cell wall compartments than intracellular compartment of $\mathrm{MeHg}$ pre-exposed plants, and these differences were significant $(\mathrm{p}<0.05$; Figure 2). For the high and low $\mathrm{MeHg}$ treatment respectively, THg in MSF was 2.9x and 2.0x higher, while BDM 5.8x and 2.3x higher for individuals fed with cell wall than intracellular compartments. To gain insights into transfer dynamics of $\mathrm{MeHg}$ in G. fossarum, we analyzed by differential centrifugation the subcellular distribution of $\mathrm{THg}$ and $\mathrm{MeHg}$ (see below) in 3 fractions (Figure 2). In controls and low MeHg treatments, $42.5 \pm 6.5 \%$ of THg was found in S2 and an equal concentration in MSF and BDM fractions $(30.0 \pm 6.1 \%)$. For gammarids fed with the high $\mathrm{MeHg}$ intracellular compartment, the MSF increased (41.0 $\pm 5.7 \%$ ), while for the high MeHg cell wall treatment the proportion of $\mathrm{THg}$ significantly increased in the BDM $(50.0 \pm 2.8 \% ; \mathrm{p}<0.05)$. We analyzed the spectrograms obtained by HPLC (Figure S1). For example, 5 peaks appeared visually increased and 4 decreased in high $\mathrm{MeHg}$ vs ctl cell wall compartments (Figure S1). Because individual peaks are poorly defined by HPLC method used here because bias are caused by the overlapping of peaks, we compared the area of peaks measured at $280 \mathrm{~nm}$ in HPLC eluting fractions normalized by the biomass of animals: the area of MTLPs-MW was increased significantly $(\mathrm{p}>0.05)$ by $1.7 \pm 0.1$ vs controls in both cell wall treatments and low intracellular treatments. Despite visual differences in peaks (Figure S1), no significant 
differences were found for the sum of areas in HMW and LMW between treatments and control. Sequestration of toxic metal by MTs and granules is a very common strategy in biota to control intracellular metal speciation and thus toxicity ${ }^{17,18} . \mathrm{MeHg}$ in bivalves and several fish preys was hypothesized to be bound in the intracellular fraction to heat-stable-protein ${ }^{54}$, 55. THg partition between the sensitive (HeSP; 40\%) and detoxified (MTLPs-MW; 60\%) fractions was previously observed in the cytosol of $C$. riparius exposed to $\mathrm{IHg}$ spiked sediments ${ }^{37}$. In the same line, during a 7 day-long depuration phase, both $\mathrm{IHg}$ and $\mathrm{MeHg}$ concentrations in G. fossarum feeding on $\mathrm{IHg}$ or $\mathrm{MeHg}$ pre-exposed E. nuttallii did not significantly vary ${ }^{10}$, supporting that in gammarids the accumulated $\mathrm{MeHg}$ was bound strongly to biological ligands, i.e. MTs and granules ${ }^{56,57,58}$. Here, this detoxification strategy could allow gammarids to reduce the toxicity of the MeHg entering their cytosol when the concentration increased.

Ratio of $\mathrm{MeHg}$ as $\mathrm{THg}$ was $111 \pm 17 \%$ in $\mathrm{S} 2$ and $\mathrm{S} 4,54.3 \pm 3.7 \%$ in $\mathrm{P} 2$ and $60.0 \pm 3.8 \%$ in $\mathrm{P} 3$. Consequently, $\mathrm{MeHg}$ proportion as $\mathrm{THg}$ increased from 68 to $95 \%$ similarly in BDM and MSF in control to high MeHg treatments, respectively ( $\mathrm{n}=3$; Table $\mathrm{S} 2)$. In our previous study with similar feeding of gammarids with $E$. nuttallii ${ }^{10}$, bioaccumulation measured on whole individuals hindered to determine where the $\mathrm{Hg}$ demethylation took place, e.g. in plant tissues before feeding (for instance, because of plant material decay or biotransformation by microbes), or during digestion or metabolization in gammarids . Here, data supported the second hypothesis, in line with observations made in $C$. riparius of an intracellular demethylation in the insoluble fraction ${ }^{11}$. These observations are consistent with a generalized demethylation of $\mathrm{MeHg}$ in experimental food chains formed by algae (70\%) and zooplankton $(13 \%)^{59}$, but contrast in natural food chains with observed $\mathrm{MeHg}$ biomagnification $^{2,31}$.

\section{Impact of dietary MeHg on proteome in G. fossarum}

\section{Number and pattern of modulated proteins}

We analyzed the whole proteome extracted from animals by shotgun proteomics and interpreted the high-resolution tandem mass spectra using a G. fossarum RNA-seq derived database. This proteogenomic approach led to 375,286 peptide-to-spectrum matches corresponding to 12,719 unique peptide sequences, resulting in 3,261 proteins identified with at least 2 peptides (Table S3). Globally, a total of 151 gammarid proteins were significantly modulated for the 4 treatment groups vs the control (Table S3). Among them, 78 were found more abundant, 67 were less abundant and 4 showed a higher abundance in intracellular but 
were less abundant in cell wall treatments. Four distinct profiles of differentially abundant proteins were identified for each treatment (Figure 3). However, a higher overlap (6-8\% of proteins) was observed in the same compartment, while only few proteins were shared between intracellular and cell wall fed gammarids (Figure 3A). Despite inter-individual variability is the main component of proteome variability in the organism analyzed in this study (Supplementary Figure 1) and as previously discussed ${ }^{44}$, the differential analysis allowed the identification of rather distinct protein profiles for each treatment (Figure 3B).

The treatment affecting the higher number of proteins was the high $\mathrm{MeHg}$ intracellular treatment that modulated the abundance of 71 proteins, in line with the higher $\%$ of $\mathrm{THg}$ found in MSF. The low MeHg cell wall and intracellular compartments modulated 45 and 44 proteins respectively. The high $\mathrm{MeHg}$ cell wall treatment modulated 36 proteins, suggesting together with the higher proportion of $\mathrm{THg}$ in BDM, the occurrence of a higher detoxification.

\section{Functional analysis of modulated proteins}

The highest measured upregulation (Fold change 55x and 52x) and downregulation (-17x, 28x) were observed for proteins involved in 'cytoskeleton' for both cell wall treatments (Table 1). The Mass of these proteins are predicted between 42-35 kDa and could be involved in the visual increase of peaks in HMW on HPCL spectrograms (Figure S1), although because the area of HPLC eluting fractions is not strictly quantitative this comparison has to be made with caution. However, these proteins are known targets of both $\mathrm{MeHg}$ and $\mathrm{IHg}$ toxicity across taxa. For example, in copepods exposed to $50 \mu \mathrm{g} \cdot \mathrm{L}^{-1} \mathrm{IHg}$ in water, authors proposed that proteins assigned to this GO term (e.g. myosin) were involved in the cell reorganization to withstand $\mathrm{Hg}$ toxicity ${ }^{60}$. Proteins involved in cytoskeleton (actin, tubulin, keratin) that are essential for vesicle trafficking were significantly modified in fish and mammals exposed to $\mathrm{IHg}$ and $\mathrm{MeHg}$ supporting cytoskeleton disruption due to metal exposures $61,62,63,64,65$. In tuna muscle, binding of $\mathrm{Hg}$ to Beta-actin encompassed approximately $34 \%$ of $\mathrm{Hg}$ in the fish muscles $^{66}$. Authors hypothesized that $\mathrm{Hg}$ binds to thiols in proteins. Here we observed that $\mathrm{S}$ represented $4.27 \pm 0.08 \%$ of residues in all samples (Table S4, Figure S3), not pointing to an increase of thiols in proteome of animals fed with $\mathrm{Hg}$ treatments.

Several modulated GO terms such as development/growth, energy metabolism, reproduction, locomotion/motility were common in all treatments (Table 2). To compare the impact of treatments on $G$. fossarum at a higher system level, we identified the most influent GOslim in the PCA as being autophagy (148), mitochondrion organization (18), ribosome biogenesis (164) and sulfur compound metabolic processes (1; Figure 4). Indeed, MeHg cell wall and 
intracellular treatment decreased and increased the level of those GO terms respectively (Table 3), suggesting a different impact of the cell wall treatment than intracellular treatment on G. fossarum cell metabolism. GOslim identified for gammarids fed with $\mathrm{MeHg}$ from the intracellular compartment supported the induction of the cellular machinery likely for replacement of damaged proteins and warranting cell functions, while in animals fed with the cell wall compartment GOslim pointed mitochondrial perturbations and the induction of autophagy, ligase and nuclease activities supporting a perturbation of cell organization triggering repair pathways. In the same line, the contrasted modulation of GO terms related to gene expression (ribosome, RNA, DNA), protein maturation (ligase and transferase activities) and growth/development supports a higher modulation of proteome by intracellular $\mathrm{MeHg}$, but a more detrimental impact to the cell metabolism of the cell wall $\mathrm{MeHg}$. As such, the tolerance mechanisms triggered by the high- $\mathrm{MeHg}$ cell wall treatment resulting in a higher proportion of THg in BDM appeared to have a cost on fitness for those animals. Data are congruent with studies on one wild G. fossarum population exposed historically to $\mathrm{Cd}$, evidencing the fitness costs and modification of toxicological sensitivities ${ }^{67}$.

Here, differentially detected GO terms are in line with several known effects of MeHg. As mentioned above, the cytoskeleton participates in the transport of molecules and signaling by vesicular trafficking involved in autophagy ${ }^{68,69}$. Autophagy is involved in elimination of aberrant or obsolete cellular structures. Mitochondria are known target of $\mathrm{MeHg}$ in animals ${ }^{63}$, ${ }^{70}$. For example, in shrimps ${ }^{203} \mathrm{Hg}$ exposure by diet resulted in $\mathrm{Hg}$ bioaccumulation in organelles (10\%) and HeSP (40\%), while in Crassostrea virginica a 4 week-long exposure to $0.056 \mu \mathrm{M} \mathrm{Hg}$ through water resulted in 16x higher concentration in organelles than MTLPs ${ }^{71,72}$. Besides, $\mathrm{MeHg}$ was shown to depolarize mitochondrial membrane in synaptosomes ${ }^{73}$. Here, bioaccumulation in mitochondria was not investigated, but this GO term supported an interaction of $\mathrm{Hg}$ with this organelle in the high $\mathrm{MeHg}$ cell wall treatment. The GO term "gene regulation" was also abundant in copepods exposed to $50 \mu \mathrm{g} \cdot \mathrm{L}^{-1} \mathrm{IHg}$ in water and in Medaka exposed to 1 and $10 \mu \mathrm{g} \cdot \mathrm{L}^{-1} \mathrm{IHg}$ in water ${ }^{60,64}$.

On the other hand, some expected GO terms were not found as significantly different, notably proteins involved in reduction-oxidation (redox) metabolism and MTs in opposition with observation of a predominant $\mathrm{BDM}$ distribution for the high $\mathrm{MeHg}$ cell wall treatment. $\mathrm{MeHg}, \mathrm{IHg}$ and other metals induce ROS production. Here, antioxidant enzymes that are often observed in response to $\mathrm{IHg}$ exposure, e.g. superoxide dismutases, peroxiredoxins and catalases ${ }^{63,64}$, were not significantly modulated at the protein level. Similarly, a proteomic 
analysis of rats exposed to $\mathrm{IHg}$ by diet did not identify GO terms directly linked to redox, despite the fact that they measured significantly increased lipid peroxidation by classical biochemical analyses ${ }^{63}$. Nevertheless, here the GO term sulfur compound metabolic process related to all chemical reactions and pathways involving sulfur-containing compounds (e.g. methionine, cysteine, glutathione) strongly influenced the distribution in the PCA among intracellular samples, while the proportion of Cysteine and Methionine residues in modulated proteins didn't changed among treatments. This suggests the preexistence in the cytosol of a sufficient pool of MTLP-MW proteins that could be involved in $\mathrm{Hg}$-chelation in cytosol, as also supported by the quite stable $\mathrm{S}$ proportion in residues of proteins for all treatments (Table S4, Figure S3). Similarly, G. fossarum specimens collected in situ from a clean and a contaminated river in Croatia showed increased soluble metal levels in gammarids in the contaminated site, but similar MT concentrations in both sites ${ }^{74}$. In the same line, Caenorhabditis elegans chronically exposed to $60 \mathrm{mg} \cdot \mathrm{L}^{-1} \mathrm{MeHg}$ showed no increase in $\mathrm{mt}$ gene expression level after $15 \mathrm{~h}$ exposure, while $m t$-gene loss-of-function mutants were markedly more sensitive than wildtype to $\mathrm{MeHg}{ }^{75}$. Nevertheless, previous studies in fish showed that MTs correlated to $\mathrm{Hg}$ concentration in liver, but not muscles and gills ${ }^{76}$. Here the proteomic analysis was conducted on whole organisms, potentially masking putative organspecific regulation. More investigation, outside the scope of the current study would be necessary to conclude on the role of MTs in the tolerance to dietary $\mathrm{MeHg}$ in our experimental conditions.

In conclusion, our analysis supported a sublethal stress likely coped by G. fossarum according to the relative low number of modulated proteins in our experimental conditions. The analysis revealed a correlation between protein abundance and $\mathrm{Hg}$ subcellular bioaccumulation in MSF, but a different protein profile for each concentration, suggesting the occurrence of several thresholds of regulation of the proteome. Data also suggested that in response to increasing doses of $\mathrm{MeHg}$, G. fossarum activated and/or deactivated some biochemical processes to compensate the loss or impairment of other pathways caused by the toxicity of $\mathrm{MeHg}$. As such, defense mechanisms triggered by dietary $\mathrm{MeHg}$ appeared to have a cost for the fitness of animals. Our experiment brought thus new insights on the specific effects of $\mathrm{MeHg}$ in diet at sublethal concentration.

Our data in addition confirmed that $\mathrm{Hg}$ bound in cell walls of plants can be assimilated by $G$. fossarum, which is consistent with its feeding strategy. The cell wall constituents are expected to remain for a long period in the environment because of their recalcitrant nature. Here, data point cell walls as a potential source of $\mathrm{Hg}$ transfers and toxicity to primary consumers. 
Moreover, proteomic analysis revealed contrasted responses for intracellular and cell wall treatments, congruent with detoxification mechanisms and supporting that the different binding sites in shoots consequently caused different toxicity to consumers. In this context feeding behaviour of consumers appears instrumental for the fate and impact of $\mathrm{Hg}$ in food chains. In particular, the abundance of species and their feeding strategy need to be considered to adequately protect aquatic systems, as both will significantly influence the fate of $\mathrm{Hg}$ in local food webs. For example, the abundance of macrophytes in shallow water systems might favor the transfer of $\mathrm{MeHg}$ to food webs.

\section{Aknowledgements}

This research received financial support by Grand Reims in the frame of the Aquasurv chair. Authors thanks Dr Rebecca Beauvais-Flück and Mr Hervé Quéau for their help during exposures. The authors also benefitted from the French GDR "Aquatic Ecotoxicology" framework which aims at fostering stimulating scientific discussions and collaborations for more integrative approaches.

\section{Supporting Information.}

Table S1: $\mathrm{Hg}$ concentrations in water, E. nuttallii and G. fossarum; Table S2: $\mathrm{Hg}$ concentration in subcellular fractions; Table S3: list of identified proteins; Tables S4 to S6: proportion of thiols in proteins; Figure S1: HPLC chromatograms, Figure S2: Principal Component Analysis and Hierarchical clustering of samples, Figure S3: proportion of thiols in proteins against fold changes.

\section{References}

1. Boening, D. W., Ecological effects, transport, and fate of mercury: a general review. Chemosphere 2000, 40, 1335-1351

2. Bravo, A. G.; Cosio, C.; Amouroux, D.; Zopfi, J.; Chevalley, P.-A.; Spangenberg, J. E.; Ungureanu, V.-G.; Dominik, J., Extremely elevated methyl mercury levels in water, sediment and organisms in a Romanian reservoir affected by release of mercury from a chloralkali plant. Wat Res 2014, 49, 391-405

3. Lawrence, A. L.; Mason, R. P., Factors controlling the bioaccumulation of mercury and methylmercury by the estuarine amphipod Leptocheirus plumulosus. Env Poll 2001, 111, 217-31 
4. UNEP, Global Mercury Assessment 2018: Sources, Emissions, Releases and Environmental Transport. Chemicals, Geneva, Switzerland. 2018

5. Amos, H. M.; Jacob, D. J.; Streets, D. G.; Sunderland, E. M., Legacy impacts of alltime anthropogenic emissions on the global mercury cycle. Glob Biogeoch Cyc 2013, 27, 410421

6. Obrist, D.; Kirk, J. L.; Zhang, L.; Sunderland, E. M.; Jiskra, M.; Selin, N. E., A review of global environmental mercury processes in response to human and natural perturbations: Changes of emissions, climate, and land use. Ambio 2018, 47, 116-140

7. Branfireun, B. A.; Cosio, C.; Poulain, A. J.; Riise, G.; Bravo, A. G., Mercury cycling in freshwater systems - An updated conceptual model. Sci Tot Env 2020, 745, 140906 8. Regier, N.; Larras, F.; Bravo, A. G.; Ungereanu, V. G.; Cosio, C., Hg bioaccumulation in the macrophyte Elodea nuttallii in the field and in microcosm: $\mathrm{Hg}$ in shoots accumulated from the water might involve $\mathrm{Cu}$ transporters. Chemosphere 2013, 90, 595-602

9. Regier, N.; Baerlocher, L.; Munsterkotter, M.; Farinelli, L.; Cosio, C., Analysis of the Elodea nuttallii transcriptome in response to mercury and cadmium pollution: development of sensitive tools for rapid ecotoxicological testing. Env Sci Tech 2013, 47, 8825-8834

10. Beauvais-Fluck, R.; Chaumot, A.; Gimbert, F.; Queau, H.; Geffard, O.; Slaveykova, V. I.; Cosio, C., Role of cellular compartmentalization in the trophic transfer of mercury species in a freshwater plant-crustacean food chain. J Haz Mat 2016, 320, 401-407

11. Beauvais-Fluck, R.; Gimbert, F.; Mehault, O.; Cosio, C., Trophic fate of inorganic and methyl-mercury in a macrophyte-chironomid food chain. $J$ Haz Mat 2017, 338, 140-147

12. Lavoie, R. A.; Bouffard, A.; Maranger, R.; Amyot, M., Mercury transport and human exposure from global marine fisheries. Sci Rep 2018, 8, 6705

13. Wu, P.; Kainz, M. J.; Bravo, A. G.; Akerblom, S.; Sonesten, L.; Bishop, K., The importance of bioconcentration into the pelagic food web base for methylmercury biomagnification: A meta-analysis. Sci Tot Env 2019, 646, 357-367

14. Graves, S. D.; Kidd, K. A.; Batchelar, K. L.; Cowie, A. M.; O'Driscoll, N. J.; Martyniuk, C. J., Response of oxidative stress transcripts in the brain of wild yellow perch (Perca flavescens) exposed to an environmental gradient of methylmercury. Comp Bioch Physiol Part C Tox Pharm 2017, 192, 50-58

15. Lee, Y. H.; Kang, H. M.; Kim, D. H.; Wang, M.; Jeong, C. B.; Lee, J. S., Adverse effects of methylmercury $(\mathrm{MeHg})$ on life parameters, antioxidant systems, and MAPK signaling pathways in the copepod Tigriopus japonicus. Aq Tox 2017, 184, 133-141 
16. Gentes, S.; Maury-Brachet, R.; Feng, C.; Pedrero, Z.; Tessier, E.; Legeay, A.; Mesmer-Dudons, N.; Baudrimont, M.; Maurice, L.; Amouroux, D.; Gonzalez, P., Specific effects of dietary methylmercury and inorganic mercury in zebrafish (Danio rerio) determined by genetic, histological, and metallothionein responses. Env Sci Tech 2015, 49, 14560-14569 17. Wallace, W. G.; Lee, B.-G.; Luoma, S. N., Subcellular compartmentalization of Cd and $\mathrm{Zn}$ in two bivalves. I. Significance of metal-sensitive fractions (MSF) and biologically detoxified metal (BDM). In Mar Ecol Prog Series, 2003; 249, 183-197.

18. Monteiro, F.; Lemos, L. S.; de Moura, J. F.; Rocha, R. C. C.; Moreira, I.; Di Beneditto, A. P.; Kehrig, H. A.; Bordon, I. C. A. C.; Siciliano, S.; Saint'Pierre, T. D.; HauserDavis, R. A., Subcellular metal distributions and metallothionein associations in roughtoothed dolphins (Steno bredanensis) from Southeastern Brazil. MarPoll Bull 2019, 146, 263273

19. Gouveia, D.; Chaumot, A.; Charnot, A.; Almunia, C.; Francois, A.; Navarro, L.; Armengaud, J.; Salvador, A.; Geffard, O., Ecotoxico-proteomics for aquatic environmental monitoring: first in situ application of a new proteomics-based multibiomarker assay using caged amphipods. Env Sci Tech 2017, 51, 13417-13426

20. Mason, R. P.; Reinfelder, J. R.; Morel, F. M. M., Uptake, toxicity, and trophic transfer of mercury in a coastal diatom. Env Sci Tech 1996, 30, 1835-1845

21. Lee, C. S.; Fisher, N. S., Bioaccumulation of methylmercury in a marine copepod. Env Tox Chem 2017, 36, 1287-1293

22. Malviya, S.; Scalco, E.; Audic, S.; Vincent, F.; Veluchamy, A.; Poulain, J.; Wincker, P.; Iudicone, D.; de Vargas, C.; Bittner, L.; Zingone, A.; Bowler, C., Insights into global diatom distribution and diversity in the world's ocean. Proc Nat Acad Sci 2016, 113, E1516

23. Tadonleke, R. D.; Lazzarotto, J.; Anneville, O.; Druart, J.-C., Phytoplankton productivity increased in Lake Geneva despite phosphorus loading reduction. J Plankton Res 2009, 31, 1179-1194

24. Descy, J.-P.; Leitao, M.; Everbecq, E.; Smitz, J. S.; Deliege, J.-F., Phytoplankton of the River Loire, France: a biodiversity and modelling study. J Plankton Res 2012, 34, 120135

25. Castro, R.; Pereira, S.; Lima, A.; Corticeiro, S.; Valega, M.; Pereira, E.; Duarte, A.; Figueira, E., Accumulation, distribution and cellular partitioning of mercury in several halophytes of a contaminated salt marsh. Chemosphere 2009, 76, 1348-1355 
26. Larras, F.; Regier, N.; Planchon, S.; Poté, J.; Renaut, J.; Cosio, C., Physiological and proteomic changes suggest an important role of cell walls in the high tolerance to metals of Elodea nuttallii. J Haz Mat 2013, 263, 575-583

27. Valega, M.; Lima, A. I.; Figueira, E. M.; Pereira, E.; Pardal, M. A.; Duarte, A. C., Mercury intracellular partitioning and chelation in a salt marsh plant, Halimione portulacoides (L.) Aellen: strategies underlying tolerance in environmental exposure. Chemosphere 2009, 74, 530-6

28. Chaumot, A.; Geffard, O.; Armengaud, J.; Maltby, L.; Amiard-Triquet, C.; Amiard, J.C.; Mouneyrac, C., Chapter 11 - Gammarids as reference species for freshwater monitoring. In Aq Ecotox, Academic Press: 2011; 253-280.

29. Boiche, A.; Lemoine, D. G.; Barrat-Segretain, M.-H.; Thiebaut, G., Resistance to herbivory of two populations of Elodea canadensis Michaux and Elodea nuttallii Planchon St. John. Plant Ecol 2011, 212, 1723-1731

30. Thiebaut, G.; Boiche, A.; Lemoine, D.; Barrat-Segretain, M.-H., Trade-offs between growth and defence in two phylogenetically close invasive species. Aq Ecol 2017, 51, 405415

31. Cosio, C.; Fluck, R.; Regier, N.; Slaveykova, V. I., Effects of macrophytes on the fate of mercury in aquatic systems. Env Tox Chem 2014, 24, 1225-1237

32. Hart, J. J.; Di Tomaso, J. M.; Linscott, D. L.; Kochian, L. V., Characterization of the transport and cellular compartmentation of paraquat in roots of intact maize seedlings. Pest Bioch Physiol 1992, 43, 212-222

33. Coulaud, R.; Geffard, O.; Xuereb, B.; Lacaze, E.; Queau, H.; Garric, J.; Charles, S.; Chaumot, A., In situ feeding assay with Gammarus fossarum (Crustacea): Modelling the influence of confounding factors to improve water quality biomonitoring. Wat Res 2011, 45, 6417-29

34. Besse, J. P.; Coquery, M.; Lopes, C.; Chaumot, A.; Budzinski, H.; Labadie, P.; Geffard, O., Caged Gammarus fossarum (Crustacea) as a robust tool for the characterization of bioavailable contamination levels in continental waters: towards the determination of threshold values. Wat Res 2013, 47, 650-60

35. Qualité de l'eau - Mesures moléculaires, physiologiques et comportementales chez le gammare (crustacé amphipode) - Partie 3 : mesure du taux d'alimentation. https://norminfo.afnor.org/consultation/xp-t90-722-3/qualite-de-leau-mesures-moleculairesphysiologiques-et-comportementales-chez-le-gammare-crustace-amphipode-partie-3/93355 
36. Geffard, A.; Sartelet, H.; Garric, J.; Biagianti-Risbourg, S.; Delahaut, L.; Geffard, O., Subcellular compartmentalization of cadmium, nickel, and lead in Gammarus fossarum: Comparison of methods. Chemosphere 2010, 78, 822-829

37. Gimbert, F.; Geffard, A.; Guedron, S.; Dominik, J.; Ferrari, B. J. D., Mercury tissue residue approach in Chironomus riparius: Involvement of toxicokinetics and comparison of subcellular fractionation methods. Aq Tox 2016, 171, 1-8

38. Rosabal, M.; Hare, L.; Campbell, P. G. C., Assessment of a subcellular metal partitioning protocol for aquatic invertebrates: preservation, homogenization, and subcellular fractionation. Limnol Ocean Met 2014, 12, 507-518

39. Cardon, P.-Y.; Caron, A.; Rosabal, M.; Fortin, C.; Amyot, M., Enzymatic validation of species-specific protocols for metal subcellular fractionation in freshwater animals. Limnol Ocean Met 2018, 16, 537-555

40. USEPA, Method 1631: Mercury in water by oxidation, purge and trap, and CVAFS. Office of Water, Revision E 2002,

41. USEPA, Method 1630: Methyl mercury in water by distillation, aqueous ethlylation, purge and trap, and CVAFS. Office of Water, draft 2001,

42. Hammerschmidt, C. R.; Fitzgerald, W. F., Methylmercury in mosquitoes related to atmospheric mercury deposition and contamination. Env Sci Technol 2005, 39, 3034-9

43. R Development Core Team, R: a language and environment for statistical computing. R Foundation for Statistical Computing. 2013, 12

44. Cogne, Y.; Almunia, C.; Gouveia, D.; Pible, O.; François, A.; Degli-Esposti, D.; Geffard, O.; Armengaud, J.; Chaumot, A., Comparative proteomics in the wild: Accounting for intrapopulation variability improves describing proteome response in a Gammarus pulex field population exposed to cadmium. Aq Tox 2019, 214, 105244

45. Hartmann, E. M.; Allain, F.; Gaillard, J. C.; Pible, O.; Armengaud, J., Taking the shortcut for high-throughput shotgun proteomic analysis of bacteria. Meth Mol Biol 2014, $2014,275-85$

46. Gouveia, D.; Cogne, Y.; Gaillard, J.-C.; Almunia, C.; Pible, O.; François, A.; DegliEsposti, D.; Geffard, O.; Chaumot, A.; Armengaud, J., Shotgun proteomics datasets acquired on Gammarus pulex animals sampled from the wild. Dat Brief 2019, 27, 104650

47. Gouveia, D.; Grenga, L.; Pible, O.; Armengaud, J., Quick microbial molecular phenotyping by differential shotgun proteomics. Env Microbiol 2020, 22: 2996-3004 
585

586

587

588

589

590

591

592

593

594

595

596

597

598

599

600

601

602

603

604

605

606

607

608

609

610

611

612

613

614

615

616

617

48. Trapp, J.; Geffard, O.; Imbert, G.; Gaillard, J.-C.; Davin, A.-H.; Chaumot, A.; Armengaud, J., Proteogenomics of Gammarus fossarum to document the reproductive system of amphipods. Mol Cell Prot 2014, 13, 3612

49. Gallais, F.; Pible, O.; Gaillard, J. C.; Debroas, S.; Batina, H.; Ruat, S.; Sandron, F.; Delafoy, D.; Gerber, Z.; Olaso, R.; Gas, F.; Bellanger, L.; Deleuze, J. F.; Grenga, L.; Armengaud, J., Heterogeneity of SARS-CoV-2 virus produced in cell culture revealed by shotgun proteomics and supported by genome sequencing. Anal Bioanal Chem 2021, 20, 1-11 50. Perez-Riverol, Y.; Csordas, A.; Bai, J.; Bernal-Llinares, M.; Hewapathirana, S.; Kundu, D. J.; Inuganti, A.; Griss, J.; Mayer, G.; Eisenacher, M.; Perez, E.; Uszkoreit, J.; Pfeuffer, J.; Sachsenberg, T.; Yilmaz, S.; Tiwary, S.; Cox, J.; Audain, E.; Walzer, M.; Jarnuczak, A. F.; Ternent, T.; Brazma, A.; Vizcaino, J. A., The PRIDE database and related tools and resources in 2019: Improving support for quantification data. Nucl Ac Res 2019, 47, D442-D450

51. Buchfink, B.; Xie, C.; Huson, D. H., Fast and sensitive protein alignment using DIAMOND. Nat Meth 2014, 12, 59-60

52. Trapp, J.; Gouveia, D.; Almunia, C.; Pible, O.; Degli Esposti, D.; Gaillard, J.-C.; Chaumot, A.; Geffard, O.; Armengaud, J., Digging deeper into the pyriproxyfen-response of the amphipod Gammarus fossarum with a next-generation ultra-high-field orbitrap analyser: new perspectives for environmental toxicoproteomics. Front Env Sci 2018, 6, 54

53. Carvalho, P. C.; Lima, D. B.; Leprevost, F. V.; Santos, M. D. M.; Fischer, J. S. G.; Aquino, P. F.; Moresco, J. J.; Yates, J. R.; Barbosa, V. C., Integrated analysis of shotgun proteomic data with PatternLab for proteomics 4.0. Nat Protocols 2016, 11, 102-117

54. Znidaric, M. T.; Falnoga, I.; Skreblin, M.; Turk, V., Induction of metallothionein-like proteins by mercury and distribution of mercury and selenium in the cells of hepatopancreas and gill tissues in mussel Mytilus galloprovincialis. Biol Trace El Res 2006, 111, 121-135

55. Dang, F.; Wang, W. X., Subcellular controls of mercury trophic transfer to a marine fish. Aq Tox 2010, 99, 500-506

56. Park, J.; Song, W. Y.; Ko, D.; Eom, Y.; Hansen, T. H.; Schiller, M.; Lee, T. G.; Martinoia, E.; Lee, Y., The phytochelatin transporters AtABCC1 and AtABCC2 mediate tolerance to cadmium and mercury. Plant J 2012, 69, 278-288

57. Gupta, M.; Tripathi, R. D.; Rai, U. N.; Chandra, P., Role of glutathione and phytochelatin in Hydrilla verticillata (lf) Royle and Vallisneria spiralis L. under mercury stress. Chemosphere 1998, 37, 785-800 
58. Tai, H. C.; Lim, C., Computational studies of the coordination stereochemistry, bonding, and metal selectivity of mercury. J Phys Chem A 2006, 110, 452-462

59. Pickhardt, P. C.; Folt, C. L.; Chen, C. Y.; Klaue, B.; Blum, J. D., Impacts of zooplankton composition and algal enrichment on the accumulation of mercury in an experimental freshwater food web. Sci Tot Env 2005, 339, 89-101

60. Xu, X.; Shi, L.; Wang, M., Comparative quantitative proteomics unveils putative mechanisms involved into mercury toxicity and tolerance in Tigriopus japonicus under multigenerational exposure scenario. Env Poll 2016, 218, 1287-1297

61. Keyvanshokooh, S.; Vaziri, B.; Gharaei, A.; Mahboudi, F.; Esmaili-Sari, A.; Shahriari-Moghadam, M., Proteome modifications of juvenile beluga (Huso huso) brain as an effect of dietary methylmercury. Comp Biochem Physiol Part D Genom Prot 2009, 4, 243248

62. Berg, K.; Puntervoll, P.; Valdersnes, S.; Goksoyr, A., Responses in the brain proteome of Atlantic cod (Gadus morhua) exposed to methylmercury. Aq Tox 2010, 100, 51-65

63. Correa, M. G.; Bittencourt, L. O.; Nascimento, P. C.; Ferreira, R. O.; Aragao, W. A. B.; Silva, M. C. F.; Gomes-Leal, W.; Fernandes, M. S.; Dionizio, A.; Buzalaf, M. R.; CrespoLopez, M. E.; Lima, R. R., Spinal cord neurodegeneration after inorganic mercury long-term exposure in adult rats: Ultrastructural, proteomic and biochemical damages associated with reduced neuronal density. Ecotox Env Saf 2020, 191, 110159

64. Wang, M.; Wang, Y.; Zhang, L.; Wang, J.; Hong, H.; Wang, D., Quantitative proteomic analysis reveals the mode-of-action for chronic mercury hepatotoxicity to marine medaka (Oryzias melastigma). Aq Tox 2013, 130-131, 123-131

65. Quintá, H. R.; Galigniana, N. M.; Erlejman, A. G.; Lagadari, M.; Piwien-Pilipuk, G.; Galigniana, M. D., Management of cytoskeleton architecture by molecular chaperones and immunophilins. Cell Sign 2011, 23, 1907-1920

66. Nong, Q.; Dong, H.; Liu, Y.; Liu, L.; He, B.; Huang, Y.; Jiang, J.; Luan, T.; Chen, B.; $\mathrm{Hu}, \mathrm{L} .$, Characterization of the mercury-binding proteins in tuna and salmon sashimi: Implications for health risk of mercury in food. Chemosphere 2021, 263, 128110.

67. Vigneron, A.; Geffard, O.; Coquery, M.; Francois, A.; Queau, H.; Chaumot, A., Evolution of cadmium tolerance and associated costs in a Gammarus fossarum population inhabiting a low-level contaminated stream. Ecotox 2015, 24, 1239-1249

68. Amaya, C.; Fader, C. M.; Colombo, M. I., Autophagy and proteins involved in vesicular trafficking. FEBS Letters 2015, 589, 3343-3353 

2017, 27, R318-R326

653 70. Ferreira, F. F.; Nazari, E. M.; Muller, Y. M. R., MeHg causes ultrastructural changes 654 in mitochondria and autophagy in the spinal cord cells of chicken embryo. $J$ Toxicol 2018, 6552018,8460490

656 71. Seebaugh, D. R.; Wallace, W. G., Assimilation and subcellular partitioning of 657 elements by grass shrimp collected along an impact gradient. Aq Tox 2009, 93, 107-115

658 72. Mass Fitzgerald, A.; Zarnoch, C. B.; Wallace, W. G., Examining the relationship 659 between metal exposure $(\mathrm{Cd}$ and $\mathrm{Hg})$, subcellular accumulation, and physiology of juvenile 660 Crassostrea virginica. Env Sci Poll Res 2019, 26, 25958-25968

661 73. Hare, M. F.; Atchison, W. D., Comparative action of methylmercury and divalent 662 inorganic mercury on nerve terminal and intraterminal mitochondrial membrane potentials. $J$ 663 Pharmacol Exp Ther 1992, 261, 166-72

664 74. Filipovic Marijic, V.; Dragun, Z.; Sertic Peric, M.; Matonickin Kepcija, R.; Gulin, V.; 665 Velki, M.; Ecimovic, S.; Hackenberger, B. K.; Erk, M., Investigation of the soluble metals in 666 tissue as biological response pattern to environmental pollutants (Gammarus fossarum 667 example). Chemosphere 2016, 154, 300-309

668 75. Helmcke, K. J.; Aschner, M., Hormetic effect of methylmercury on Caenorhabditis 669 elegans. Tox Appl Pharmacol 2010, 248, 156-164

670 76. Bebianno, M. J.; Santos, C.; Canario; J.; Gouveia, N.; Sena-Carvalho, D.; Vale, C., Hg 671 and metallothionein-like proteins in the black scabbardfish Aphanopus carbo. Food Chem Tox 672 2007, 45, 1443-1452

673

674 
Table 1. List of the five most up and down-detected proteins in each treatment. Abundance vs control (Log2 fold change), annotation, \% identities and e-value are listed. Values in bold are significantly different to control (p-value $<0.05$ calculated with univariate statistic: Ttest).

\begin{tabular}{|c|c|c|c|c|c|c|}
\hline Functional annotation & $\begin{array}{l}\text { \% sequence } \\
\text { identity }\end{array}$ & $\begin{array}{l}\text { Expect } \\
\text { value } \\
\end{array}$ & I-low & I-high & C-low & C-high \\
\hline \multicolumn{7}{|l|}{ Cell structure } \\
\hline actin, cytoplasmic 1 & 51.3 & $1.5 e-58$ & 1.1 & -1.8 & 55.2 & $\mathbf{5 3 . 0}$ \\
\hline myosin light chain alkali-like & 53.8 & $5.9 \mathrm{e}-23$ & -2.3 & -5.3 & 2.2 & 1.7 \\
\hline tubulin alpha- 3 chain & 75.2 & $7.1 \mathrm{e}-135$ & 5.1 & 18.1 & -1.7 & -1.7 \\
\hline myosin heavy chain, muscle-like isoform X18 & 76.1 & $1.7 \mathrm{e}-70$ & 1.1 & 6.1 & -11.5 & -4.9 \\
\hline myosin heavy chain type b & 58.7 & $2.6 e-69$ & -1.0 & 5.9 & -7.1 & -7.0 \\
\hline collagen alpha-1, IV, chain precursor, putative & 63.5 & $1.2 \mathrm{e}-61$ & -1.7 & -2.7 & -2.3 & -7.9 \\
\hline myosin heavy chain, partial & 83.8 & $2.9 \mathrm{e}-79$ & 2.2 & 17.1 & -17.3 & -28.3 \\
\hline \multicolumn{7}{|l|}{ Energy metabolism } \\
\hline ADP/ATP translocase 3-like & 94 & $1.4 \mathrm{e}-44$ & -8.0 & -2.2 & 7.2 & 5.7 \\
\hline fructose-bisphosphate aldolase & 85.7 & $5.8 \mathrm{e}-31$ & 7.0 & 2.7 & 1.1 & -1.0 \\
\hline sucrase-isomaltase, intestinal & 59.8 & $9,00 \mathrm{E}-102$ & -6.4 & -2.6 & -2.1 & -1.1 \\
\hline glycogen phosphorylase & 67.4 & $2.5 e-98$ & 6.4 & 8.6 & -1.9 & -1.2 \\
\hline aconitate hydratase, mitochondrial & 91.6 & $2.4 \mathrm{e}-168$ & 3.9 & 6.5 & 1.4 & -1.2 \\
\hline endoglucanase E-4 & 72 & $5.1 \mathrm{e}-147$ & -4.4 & -5.4 & -3.0 & -1.2 \\
\hline malate dehydrogenase, cytoplasmic & 87.8 & $4.1 \mathrm{e}-161$ & 3.9 & 6.0 & -1.1 & -1.6 \\
\hline enolase isoform X1 & 77.7 & $1.7 \mathrm{e}-113$ & -14.1 & -3.0 & -6.0 & -5.1 \\
\hline family 7 cellobiohydrolase & 77.9 & $6.7 e-61$ & 1.4 & -8.9 & -2.1 & -7.9 \\
\hline \multicolumn{7}{|l|}{ Response to stress } \\
\hline endoplasmin-like isoform X1 & 78.5 & $5.2 \mathrm{e}-177$ & 3.4 & 2.2 & 6.8 & 7.1 \\
\hline oplophorus-luciferin 2-monooxygenase non-catalytic subunit & 34 & $4.4 \mathrm{e}-46$ & 2.1 & 1.7 & 5.3 & 3.3 \\
\hline glucosylceramidase-like & 73.6 & $4.5 e-56$ & -4.1 & -6.2 & 2.1 & 2.1 \\
\hline phosphate carrier protein, mitochondrial-like & 81.3 & $2.5 \mathrm{e}-119$ & -2.0 & -7.5 & 1.2 & 1.5 \\
\hline hemolymph clottable protein-like isoform X1 & 31.6 & $1.1 \mathrm{e}-06$ & 4.3 & 3.1 & 2.8 & 1.3 \\
\hline putative glucosylceramidase 3 & 63.8 & $7.9 \mathrm{e}-42$ & -1.3 & -1.2 & 4.5 & 1.0 \\
\hline
\end{tabular}


dehydrogenase/reductase SDR family member 4 beta-1,3-glucan binding protein

endoplasmin-like isoform $\mathrm{X} 2$

\section{Others}

putative glucosylceramidase 3

putative ferric-chelate reductase 1 homolog

uncharacterized protein

uncharacterized protein

uncharacterized protein

uncharacterized protein

$\begin{array}{llllll}56.1 & 3.5 \mathrm{e}-45 & \mathbf{4 . 4} & -1.3 & 1.8 & -1.0 \\ 38 & 3.7 \mathrm{e}-41 & -1.5 & 3.1 & \mathbf{- 6 . 5} & \mathbf{- 8 . 6} \\ 70 & 5.5 \mathrm{e}-135 & -1.0 & 2.4 & \mathbf{- 8 . 8} & \mathbf{- 8 . 7}\end{array}$

$\begin{array}{llllll}55.8 & 6.2 \mathrm{e}-115 & 1.1 & -2.5 & 2.5 & \mathbf{6 . 2}\end{array}$

$\begin{array}{llllll}30.3 & 1.7 & 1.3 & -3.1 & 4.3 & \mathbf{5 . 2}\end{array}$

$\begin{array}{llllll}49.5 & 9.2 \mathrm{e}-43 & 1.1 & 4.0 & 2.3 & \mathbf{1 5 . 3}\end{array}$

$\begin{array}{llllll}29.9 & 7.9 \mathrm{e}-55 & 1.1 & -1.2 & \mathbf{4 . 5} & 2.9\end{array}$

$\begin{array}{llllll}56 & 4.2 \mathrm{e}-61 & \mathbf{6 . 7} & \mathbf{7 . 5} & 3.2 & 1.7\end{array}$

$\begin{array}{llllll}61.9 & 1.4 \mathrm{e}-78 & -1.9 & \mathbf{- 4 . 7} & -1.7 & 1.1\end{array}$

$\begin{array}{lll}-1.9 & \mathbf{- 4 . 7} & -1.7\end{array}$ 
Table 2. Ratio of GOslim terms for molecular function (MF), biological process (BP) and cellular compartment (CC) showing opposite trends for $G$. fossarum feeding on the low or high MeHg contaminated intracellular (I) or cell wall (C) compartment vs respective controls of E. nuttallii. Values in bold are significantly different to control (Log2 fold change, *pvalue $<0.05$ calculated with univariate statistic: Ttest).

\begin{tabular}{|c|c|c|c|c|c|}
\hline & & I-low & I-high & C-low & C-high \\
\hline GOslim_MF & cytoskeletal protein binding & $3.7 *$ & $1.7 *$ & -3.0 & -1.1 \\
\hline GOslim_MF & enzyme binding & $2.0 *$ & 1.7 & -1.8 & -2.0 \\
\hline GOslim_MF & DNA binding & $3.0 *$ & 1.9 & $-2.2 *$ & $-1.1^{*}$ \\
\hline GOslim_MF & ATPase activity & $3.0 *$ & 1.3 & -2.0 & -1.2 \\
\hline GOslim_BP & plasma membrane organization & $3.0 *$ & $1.7^{*}$ & $2.5^{*}$ & -2.8 \\
\hline GOslim_BP & anatomical structure development & $1.1 *$ & 1.1 & -2.0 & $-1.1 *$ \\
\hline GOslim_BP & $\begin{array}{l}\text { anatomical structure formation involved } \\
\text { in morphogenesis }\end{array}$ & $3.7 *$ & $1.6^{*}$ & -1.4 & $-1.4^{*}$ \\
\hline GOslim_BP & circulatory system process & $2.9 *$ & 1.5 & -3.6 & -2.3 \\
\hline GOslim_BP & embryo development & $3.6^{*}$ & 1.5 & -3.2 & $-1.8^{*}$ \\
\hline GOslim_BP & reproduction & $1.7 *$ & 1.5 & -1.9 & $-1.5^{*}$ \\
\hline GOslim_BP & growth & $1.1 *$ & $2.0^{*}$ & -2.8 & -2.4 \\
\hline GOslim_BP & locomotion & $1.7 *$ & 1.4 & -1.3 & $-1.4^{*}$ \\
\hline GOslim_BP & cell motility & $3.8 *$ & 1.4 & -2.2 & $-1.5^{*}$ \\
\hline GOslim_CC & chromosome & $4.2 *$ & 1.1 & -3.7 & -1.2 \\
\hline GOslim_CC & cytosol & $1.0 *$ & $1.3^{*}$ & -1.5 & -1.3 \\
\hline GOslim_CC & nucleoplasm & $1.4 *$ & 1.8 & $-1.3^{*}$ & $-2.3^{*}$ \\
\hline GOslim_CC & microtubule organizing center & $5.5 *$ & 6.0 & 2.9 & -2.8 \\
\hline GOslim_CC & protein-containing complex & $1.1 *$ & 1.3 & -1.2 & $-1.1^{*}$ \\
\hline
\end{tabular}


Table 3. Ratio of GO terms responding to concentration for G. fossarum feeding on the low and high $\mathrm{MeHg}$ contaminated intracellular (I) and cell wall compartment (C) vs respective controls of E. nuttallii (Log2 fold change; *p-value <0.05; \#N/A GO term not found for the treatment).

\begin{tabular}{llccccc}
\hline & & $\begin{array}{c}\text { GO Term \# } \\
\text { on PCA }\end{array}$ & I-low & I-high & C-low & C-high \\
\hline GOslim_BP & autophagy & 148 & $-5.1^{*}$ & 0.8 & -0.2 & 4.8 \\
GOslim_BP & mitochondrion organization & 18 & $-2.9^{*}$ & 0.6 & -4.4 & 4.8 \\
GOslim_BP & ribosome biogenesis & 164 & \#N/A & 2.4 & -5.6 & \#N/A \\
& & & & & & \\
GOslim_CC & microtubule organizing center & 198 & $5.5^{*}$ & 6.0 & 2.9 & -2.8 \\
& & & & & & \\
GOslim_CC & ribosome & 207 & \#N/A & 2.4 & -5.6 & $-4.9^{*}$ \\
& & & & & & \\
& & & & & & \\
GOslim_MF & $\begin{array}{l}\text { transferase activity, transferring } \\
\text { glycosyl groups }\end{array}$ & 5 & $5.9^{*}$ & $5.8^{*}$ & -5.1 & \#N/A \\
GOslim_MF & ligase activity & & & & & \\
GOslim_MF & rRNA binding & & & & & \\
GOslim_MF & structural constituent of ribosome & 75 & \#N/A & 2.4 & -5.6 & $-4.9^{*}$ \\
\hline
\end{tabular}




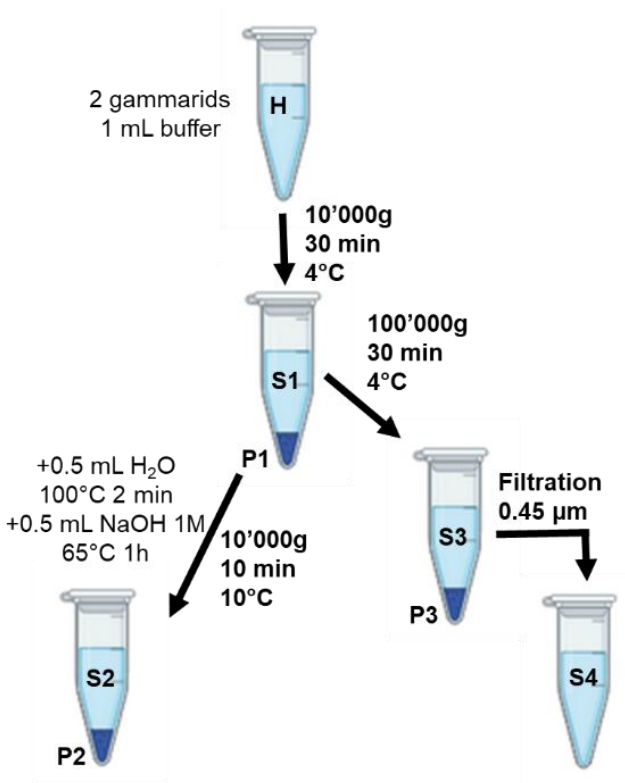

Figure 1. main steps of differential centrifugation protocol. 

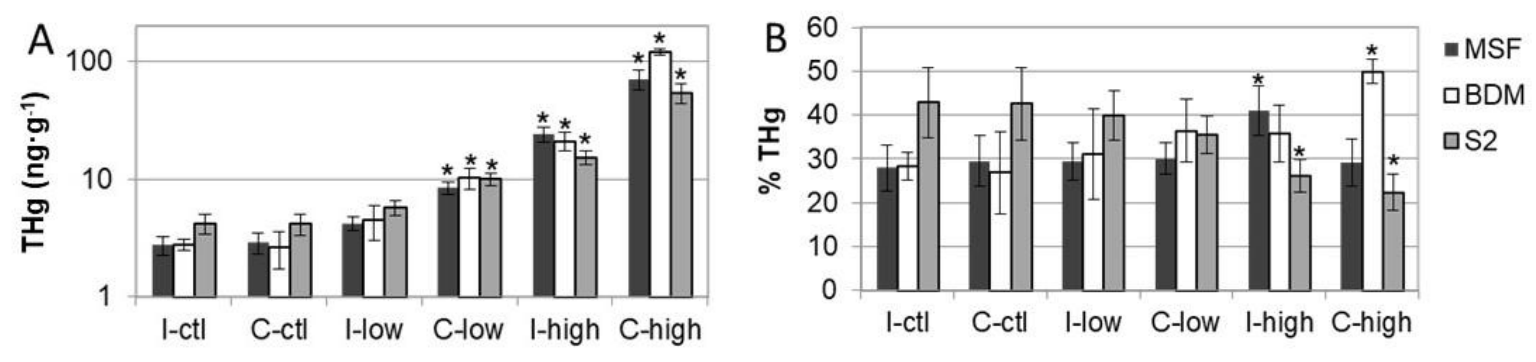

Figure 2. Concentration (ng. $\mathrm{g}^{-1}$; mean $\left.\pm \mathrm{sd} ; \mathrm{A}\right)$ and proportion $(\% ; \mathrm{B})$ of $\mathrm{THg}$ measured in MSF, BDM and debris (S2) for G. fossarum feeding on the MeHg contaminated intracellular (I) or cell wall (C) compartment of E. nuttallii $\left({ }^{*} p<0.05\right.$ vs control; $\mathrm{n}=3$ ). 


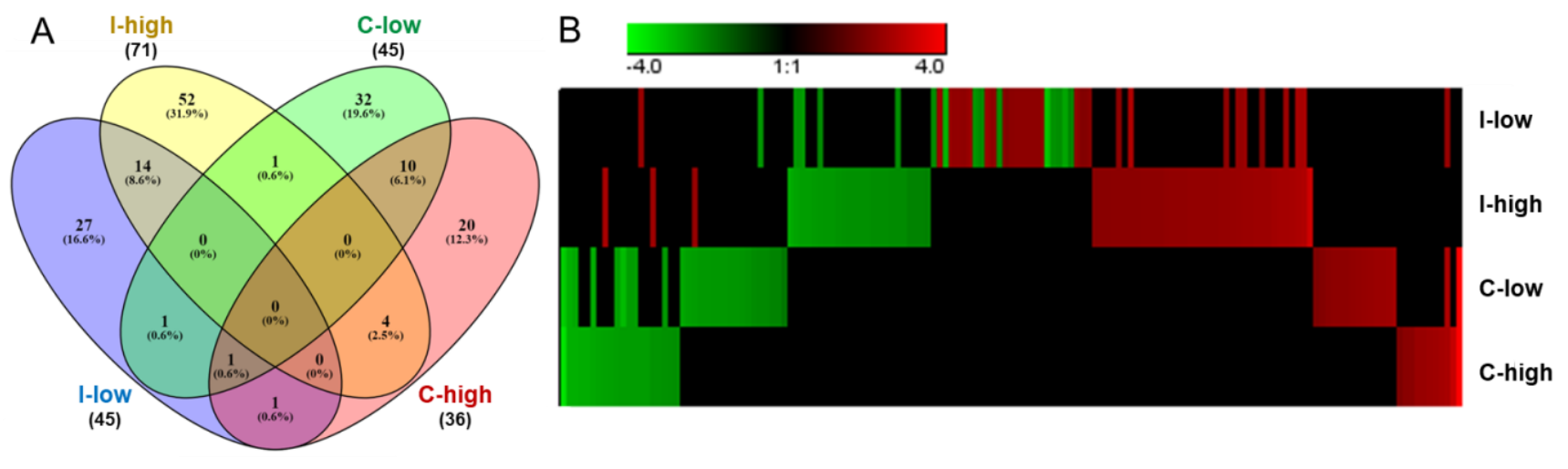

Figure 3: Venn diagram (A) and heatmap (Log2 fold change) (B) of differentially abundant proteins in G. fossarum feeding 7 days on the low or high MeHg contaminated intracellular (I) or cell wall (C) vs control ( $p$-value <0.05). Maximum of heatmap is set to 4 for visibility of smaller fold changes (see Table 1 for identification of most modulated proteins). 


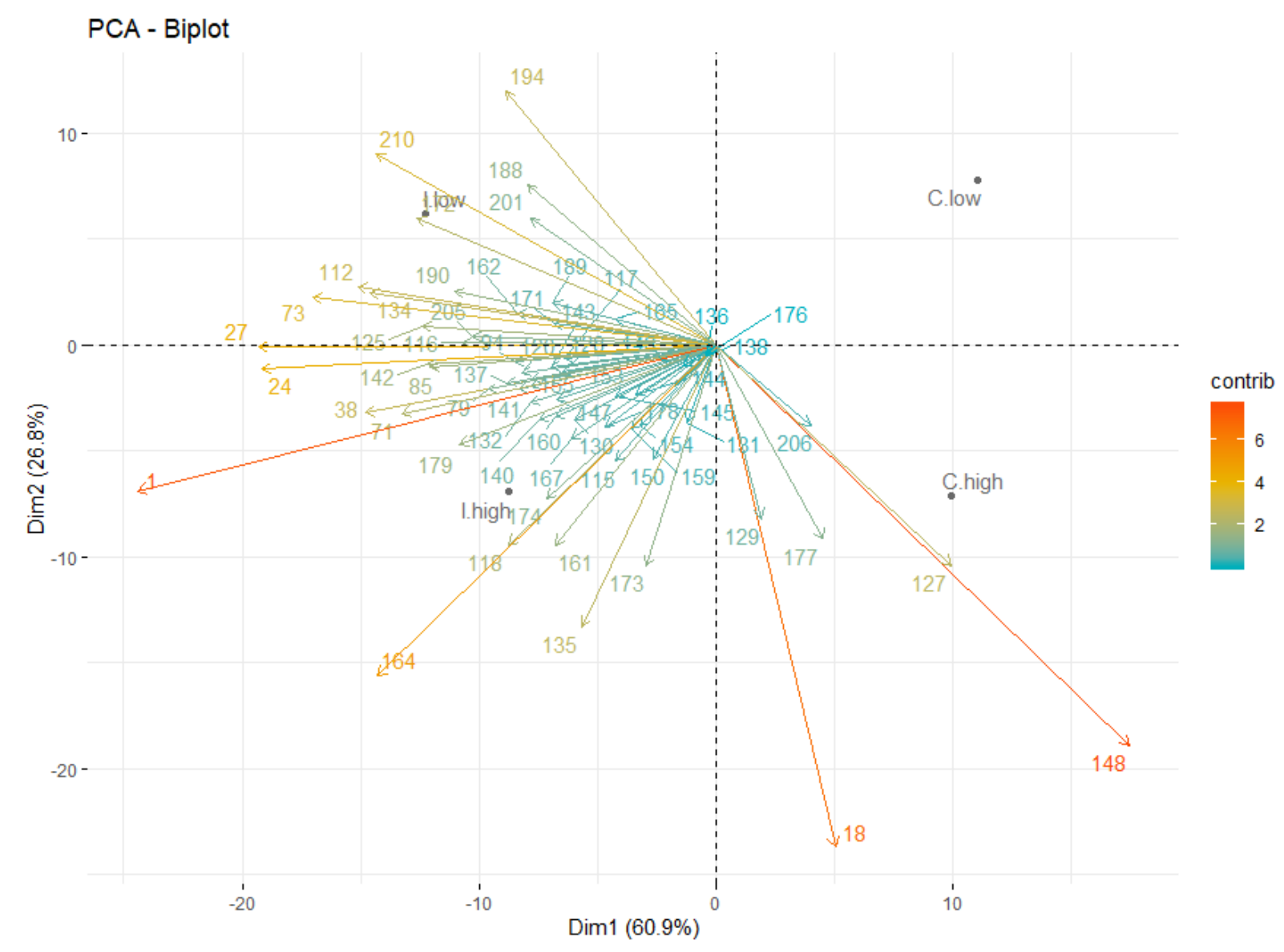

Figure 4. PCA of GOslim terms according to biological processes in G. fossarum feeding 7 days on the low or high MeHg contaminated intracellular (I) or cell wall (C) vs control. 